UDC 341.942 .3

LBC 67.93

\title{
SOME PROBLEMS OF IMPROVING THE CRIMINAL PROCEDURE LEGISLATION AND THE NEED FOR THE ADOPTION OF THE NEW CRIMINAL PROCEDURE CODE OF THE RUSSIAN FEDERATION
}

\author{
Anatoliy P. Kruglikov \\ Volgograd State University, Volgograd, Russian Federation
}

Introduction: the current criminal procedure legislation, which serves, among other things, as a means of ensuring the human and civil rights and freedoms, as a means of ensuring the national security, is constantly changing and being supplemented, and such changes and additions are perceived ambiguously, sometimes sharply criticized by the scientists and practitioners. Results: the article analyzes the reasons for making numerous changes and additions, proposes measures to improve the criminal procedure legislation. Conclusions: the fact that it is necessary to adopt the criminal procedure code in a new version is obvious and justified. The results of the study can be used in the improvement of the criminal procedure legislation, as well as in the investigative and judicial practice.

Key words: changes and amendments to the Criminal Procedure Code, the need for adopting the Criminal Procedure Code in the new edition.

УДК 341.942 .3

ББК 67.93

\section{НЕКОТОРЫЕ ПРОБЛЕМЫ СОВЕРШЕНСТВОВАНИЯ УГОЛОВНО-ПРОЦЕССУАЛЬНОГО ЗАКОНОДАТЕЛЬСТВА И НЕОБХОДИМОСТЬ ПРИНЯТИЯ НОВОГО УПК РФ}

\author{
Анатолий Петрович Кругликов \\ Волгоградский государственный университет, г. Волгоград, Российская Федерация
}

\begin{abstract}
Введение: действующее уголовно-процессуальное законодательство, которое служит в том числе и средством обеспечения прав и свобод человека и гражданина, средством обеспечения национальной безопасности, постоянно изменяется и дополняется, причем такие изменения и дополнения научными и практическими работниками воспринимаются неоднозначно, порой достаточно резко критикуются. Результаты: в пределах установленного для статьи объема в ней анализируются причины внесения многочисленных изменений и дополнений, предлагаются меры по совершенствованию уголовно-процессуального законодательства. Выводы: представляется очевидным и обосновывается тот факт, что необходимо принимать УПК РФ в новой редакции. Результаты проведенного исследования могут быть использованы при совершенствовании уголовно-процессуального законодательства, а также в следственной и судебной практике.

Ключевые слова: изменения и дополнения в УПК РФ, необходимость принятия УПК РФ в новой редакции.
\end{abstract}

\section{Введение}

Необходимо отметить, что после введения в действие УПК РФ (далее - УПК) ста- ли приниматься законы, изменяющие, в том числе, первоначальную его направленность. Причем многочисленные и значительные изменения и дополнения не оказали какого-ни- 
будь значительного улучшения содержания УПК, а порой и ухудшили его.

Рассмотрим лишь некоторые последствия указанных изменений и дополнений в УПК.

Отметим, что указанные изменения и дополнения в УПК вносились без какого-либо предварительного известного и значительного их обсуждения с научными и практическими работниками.

Результаты указанных изменений, например, правового положения прокурора, видны из доклада Генерального прокурора РФ Ю.И. Чайки, сделанного им на заседании Совета Федерации Федерального собрания Российской Федерации 18 апреля 2018 года.

Оценивая общее состояние преступности в стране, он, в частности, отметил, что в 2017 г. увеличилось количество выявленных прокурорами на досудебной стадии нарушений закона (5,2 млн). По делам следователей на четверть возросло число оправданных судом $(+28 \%, 877)$, а общее количество лиц, получивших право на реабилитацию, превысило 13 тысяч $(+3,6 \%)$. С учетом отмеченного и других данных, Ю.И. Чайкой сделан вывод о необходимости возвращения полноценного прокурорского надзора за процессуальной деятельностью органов предварительного расследования и о предоставлении прокурорам права возбуждать и расследовать уголовные дела, в частности, в отношении следователей [4].

О многочисленных фактах нарушений законности на досудебных стадиях уголовного процесса сообщается и в Докладе о деятельности уполномоченного по правам человека в Российской Федерации за 2017 г., опубликованном в Российской газете 17 апреля 2018 года. В разделе доклада, посвященном защите прав человека в уголовном судопроизводстве, отмечен рост в 2017 г. количества обращений граждан по вопросу обоснованности привлечения к уголовной ответственности. В докладе также говорится о том, что возросло количество обращений граждан и по вопросам, связанным с нарушением их прав при приеме, регистрации и рассмотрении заявлений о преступлении $(+17,6 \%)$, с нарушением права на защиту (+ $11 \%$ ), с обоснованностью привлечения к уголовной ответ- ственности (+ $11,8 \%)$, с арестами и сроками содержания под стражей $(+4,5$ \%).

\section{О ряде современных проблем, относящихся к положениям УПК}

В одной статье установленного небольшого объема нельзя подробно рассмотреть имеющиеся проблемы уголовно-процессуального законодательства, поэтому затронем лишь некоторые из них. Примечательно, что своими изменениями и дополнениями УПК законодатель почему-то не устраняет казалось бы видимые и известные недостатки, а порождает новые.

Так, в п. 46 ст. 5 УПК, содержащей ocновные понятия, используемые в УПК, в числе участников процесса почему-то не указан подозреваемый, но в главе 7 «Участники уголовного судопроизводства со стороны защиты» он назван первым.

Серьезным недостатком УПК является отсутствие в главе второй, называющей принципы уголовного процесса, таких принципов, содержащихся в Конституции РФ, как принцип равенства всех перед законом и судом, принцип публичности и принцип гласности.

Иногда одно и то же понятие обозначается разными терминами. Так, в п. 22 ст. 5 УПК дано понятие обвинения - под ним понимается утверждение о совершении определенным лицом деяния, запрещенного уголовным законом, выдвинутое в порядке, установленном УПК. В п. 55 ст. 5 УПК РФ содержится определение уголовного преследования как процессуальной деятельности, осуществляемой стороной обвинения в целях изобличения подозреваемого, обвиняемого в совершении преступления. Однако в УПК имеются положения, трактующие обвинение и уголовное преследование как синонимы. Например, в п. 45 ст. 5 УПК говорится о «функции обвинения (уголовного преследования)». В ч. 2 ст. 15 УПК - о «функции обвинения».

Следует отметить и еще одно противоречие в УПК: в ст. 140, которая называется «Поводы и основания для возбуждения уголовного дела», в ч. 1, содержащую перечень указанных поводов, Федеральным законом от 28.12.2010 г. № 405 Ф3 включен новый пункт «4) постановление прокурора о направлении 
соответствующих материалов в орган предварительного расследования для решения вопроса об уголовном преследовании». И здесь возникает вопрос: п. 4 в ч. 1 ст. 140 УПК введен новый повод для возбуждения уголовного дела или повод для решения вопроса об уголовном преследовании? Может быть, законодатель считает, что возбуждение уголовного дела и возбуждение уголовного преследования - это одно и то же? В УПК ответ на этот вопрос отсутствует.

\section{О незначительном количестве оправдательных приговоров в РФ и некоторых причинах этого}

И еще один важный вопрос, который, на мой взгляд, заслуживает глубоко изучения и обсуждения научными и практическими работниками. Необходимость его изучения и обсуждения диктуется тем, что в России выносится очень мало оправдательных приговоров, причины такого явления активно обсуждаются практическими и научными работниками. О малом количестве оправдательных приговоров указывается и в вышеназванном докладе о деятельности уполномоченного по правам человека в РФ за 2017 г.: «Вызывает озабоченность проблема незначительного количества оправдательных приговоров. В 2017 г. обвинительные приговоры постановлены по 99,6 \% рассматриваемых уголовных дел, и только 0,4 \% приговоров стали оправдательными».

К другой причине, помимо обвинительного уклона в деятельности судов, к моему глубокому убеждению можно отнести то обстоятельство, что перед судом в соответствии с действующим в настоящее время законом находится не подозреваемый в совершении преступления, а обвиняемый (подсудимый).

Если бы из УПК был исключен такой участник процесса, как обвиняемый, а был оставлен только подозреваемый, то, убежден, это заставляло бы органы предварительного расследования более тщательно собирать и анализировать доказательства его виновности или невиновности в совершении преступления. И судья, понимая, что перед ним на скамье подсудимых лицо, лишь подозреваемое в совершении преступления, несомненно, гораздо внимательнее относился бы к исследованию и оценке имеющихся в деле доказательств и доказательств, полученных в ходе судебного следствия.

\section{О необходимости принятия УПК в новой редакции}

Изменения и дополнения УПК, затронувшие многие основополагающие его положения, повлекли за собой обоснованные суждения многих авторов о необходимости принятия нового УПК или новой его редакции.

Так, профессор В.И. Зажицкий в журнале «Государство и право» отметил, что идея разработки УПК в новой редакции поддержана учеными и практическими работниками. Задача состоит в том, чтобы создать такой УПК, который в большей мере учитывал бы современные российские реалии и отвечал бы потребностям судебно-следственной практики. Конечно, полагает он, это исключительно сложная задача, но в интересах общества и государства она должна быть решена безотлагательно [1, с. 61-67].

Профессор А.В. Смирнов в своей большой статье «Почему России нужен новый Уголовно-процессуальный кодекс», опубликованной в журнале «Уголовный процесс», осветил имеющиеся, по его мнению, основные пороки действующего УПК и их истоки [3, с. 74-86].

При разрешении вопроса о содержании нового УПК необходимо, как представляется, тщательно проанализировать содержание глав $40,40^{1}$ и $32^{1}$, устанавливающих особый порядок принятия судебного решения, при котором можно не устанавливать все обстоятельства, указанные в ст. 73 УПК, а также не исследовать их должным образом при проведении предварительного расследования и рассмотрении дела в суде. Думается, что реализация положений названных выше статей в значительной мере противоречит целям уголовного наказания, закрепленным в ст. 43 УК РФ - таким, как восстановление социальной справедливости, исправление осужденного и предупреждение совершения новых преступлений.

Нуждаются в совершенствовании и нормы, регулирующие взаимодействие следователей и органов дознания, благодаря которо- 
му раскрываются многие тяжкие и особо тяжкие преступления.

Имеется еще немало проблем, относящихся к действующему уголовно-процессуальному законодательству РФ, на которые хотелось бы обратить внимание коллег, но ограниченный объем статьи не позволяет сделать это.

До принятия нового УПК известный адвокат, член Общественной палаты РФ, председатель Общественного совета при МВД РФ профессор А. Кучерена предлагает, в частности, «...объявить мораторий на принятие поправок в действующие законы» [2].

\section{Выводы}

Анализ многочисленных существенных изменений и дополнений в УПК и взглядов научных и практических работников, к ним относящихся, приводит к выводу о том, что названные изменения и дополнения являются основанием для внесения предложений по подготовке нового УПК или новой его редакции.

Для этого необходимо, по моему мнению, образовать при Государственной Думе РФ комиссию с включением в нее известных ученых и опытных практических работников, с участием представителей из заинтересованных министерств и ведомств - для подготовки проекта УПК. Затем опубликовать данный проект для широкого обсуждения и с учетом его результатов принять УПК в новой редакции.

\section{СПИСОК ЛИТЕРАТУРЫ}

1. Зажицкий, В. И. Прокурор в уголовном процессе / В. И. Зажицкий // Государство и право. - 2016. - № 6. - С. 61-70.

2. Кучерена, А. Г. Правосудие - и никаких сделок / А. Г. Кучерена // Российская газета. - 2015. 20 января (№ 6579).

3. Смирнов, А. В. Почему России нужен новый Уголовно-процессуальный кодекс / А. В. Смирнов // Уголовный процесс. - 2014. - № 9. - С. 74-86.

4. Чайка, Ю. И. Доклад на заседании Совета Федерации Федерального собрания Российской Федерации 18 апреля 2018 года. - Электрон. текстовые дан. - Режим доступа: http:/genproc.gov.ru/smi/ interview_and appearences/appearences/1367434. Загл. с экрана.

\section{REFERENCES}

1. Zazhitskiy V.I. Prokuror v ugolovnom protsesse [The Prosecutor in Criminal Trial]. Gosudarstvo i pravo, 2016, no. 6, pp. 61-70.

2. Kucherena A.G. Pravosudie - i nikakikh sdelok [Justice and no Bargains]. Rossiyskaya gazeta, 2015, January 20 (no. 6579).

3. Smirnov A.V. Pochemu Rossii nuzhen novyy Ugolovno-protsessualnyy kodeks [Why Russia Needs a New Criminal Procedure Code?]. Ugolovnyy protsess, 2014, no. 9, pp. 74-86.

4. Chayka Yu.I. Doklad na zasedanii Soveta Federatsii Federalnogo sobraniya Rossiyskoy Federatsii 18 aprelya 2018 goda [Yu.I. Chaika's Report at the Meeting of the Federation Council of Federal Assembly of Russia on April 18, 2018]. URL: http:// genproc.gov.ru/smi/interview_and_appearences/ appearences/1367434.

\section{Information about the Author}

Anatoliy P. Kruglikov, Candidate of Sciences (Jurisprudence), Honored Worker of Higher Vocational Education of the Russian Federation, Professor, Department of Criminal Process and Criminalistics, Volgograd State University, Prosp. Universitetsky, 100, 400062 Volgograd, Russian Federation, upik@volsu.ru.

\section{Информация об авторе}

Анатолий Петрович Кругликов, кандидат юридических наук, почетный работник высшего профессионального образования РФ, профессор кафедры уголовного процесса и криминалистики, Волгоградский государственный университет, просп. Университетский, 100, 400062 г. Волгоград, Российская Федерация, upik@volsu.ru. 